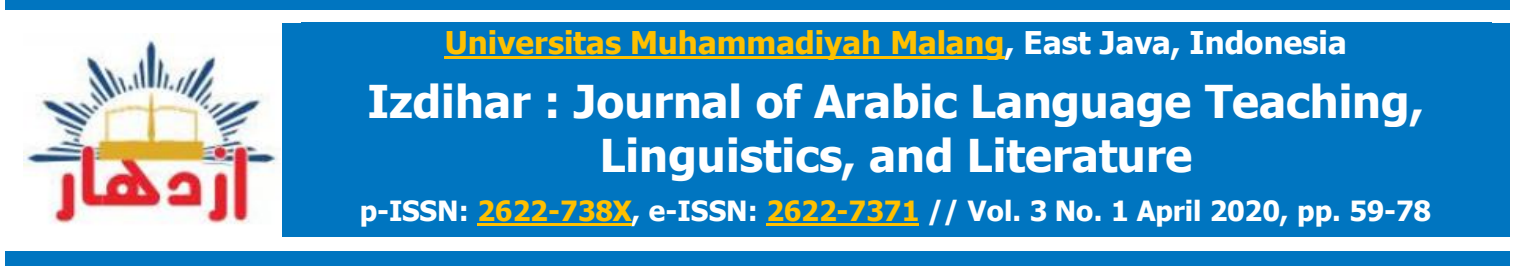

do:

\title{
Mediated Arabic Language Learning for Arabic Students of Higher Education in COVID-19 Situation
}

\author{
Wildana Wargadinataa,1, Iffat Maimunah ${ }^{b, 2}$, Suci Ramadhanti Febrianic,3, Luluk \\ Humaira d,4 \\ a,bUniversitas Islam Negeri Maulana Malik Ibrahim Malang, Indonesia \\ 'Universitas Islam Negeri Imam Bonjol Padang, Indonesia \\ dInstitut Agama Islam Negeri Samarinda, Indonesia \\ 1wildana@bsa.uin-malang.ac.id*,2iffatmaimunah@uin-malang.ac.id, \\ 3suciramadhantifebriani11@gmail.com, ${ }^{4}$ luluk.humaira@iain-samarinda.ac.id
}

\section{ARTICLE INFO}

\section{Article History:}

Received: $13 / 04 / 2020$

Revised: 21/04/2020

Accepted: $29 / 04 / 2020$

Published: $30 / 04 / 2020$

\section{*Corresponding \\ Author:}

Name:

Wildana Wargadinata

Email: wildana@bsa.uin-

malang.ac.id

\section{ABSTRACT}

The COVID-19 emergency situation has affected all citizens of the world, including Indonesia and also all non-formal and formal educational institutions, such as higher educations. The Learning Process in various educational units, including tertiary institutions, experienced a total change to the use of internet or online media. The present article examines the media and the Arabic learning process at the university in the COVID-19 pandemic situation. The COVID-19 pandemic situation changed the way of learning Arabic students at UIN Maulana Malik Ibrahim Malang from conventional offline learning to learning using internet media online. This research is a qualitative descriptive study. The data are obtained through observation, questionnaires distributed through Google forms, online interviews through social media, and documentation. The result shows that the majority of students use the WhatsApp application, and most of them study autonomously through online platforms. Besides, it reveals that the most popular learning material is video. To improve their language skills, students are more likely to have peerdiscussion activities. The study discovered a shift in Arabic learning by students of UIN Maulana Malik Ibrahim Malang from personal to instrumental as a result of the current COVID-19 pandemic situation. In this case, there was a transformation in Arabic learning from a personalcultural approach to an instrumental-functional approach. This research has implications regarding the ideal Arabic learning process in the conditions of the COVID-19 pandemic. The shift also took place in the degree of teachers' dependence towards dependence on technology during the pandemic situation.

Copyright (c) 2020, Wargadinata et al This is an open access article under the CC-BY-SA license

Arabic Language Learning, COVID-19, Media

\section{Keyword}

$$
\text { مستخلص البحتث }
$$

أثرت حالة الطوارئ COVID-19 على جميع مواطني العالم ، بما في ذلك إندونيسيا وأيضًا جميع المؤسسات التعليمية الرسمية وغير الرسمية ، مثل التعليم العالي.

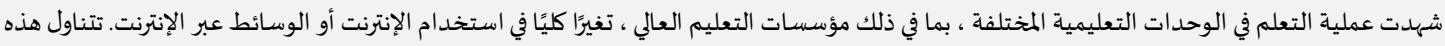

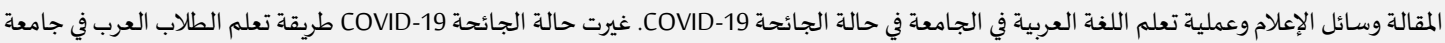

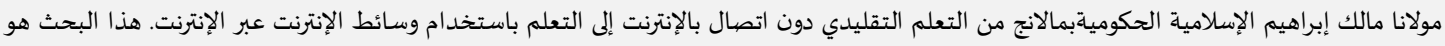

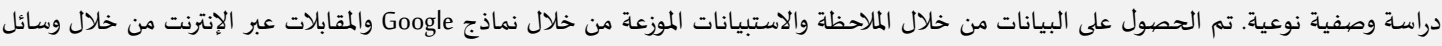

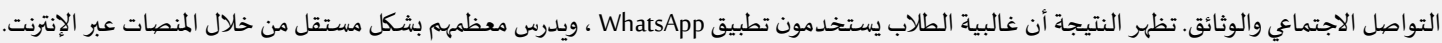

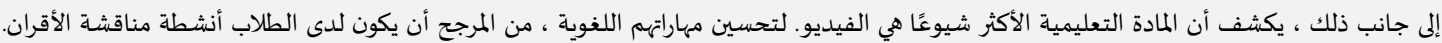

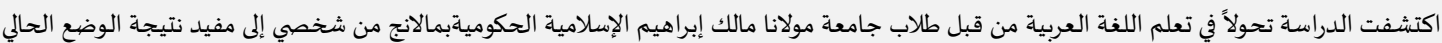

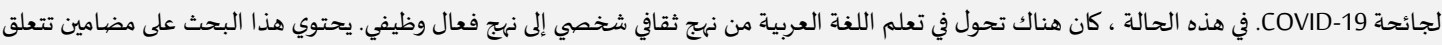

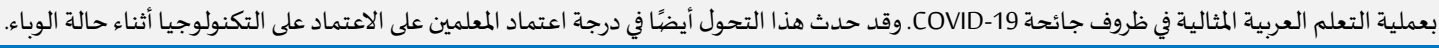

$$
\text { كلمات أساسية }
$$

Please cite this article as Wargadinata, W., Maimunah, I., Febriani, S. R., Humaira, L. (2020). Mediated

Arabic Language Learning for Higher Education in COVID-19 Situation. Izdihar: Journal of Arabic Language Teaching, Linguistics, and Literature, 3(1), 59-78. DOI: https://doi.org/10.22219/jiz.v3i1.11862 


\section{INTRODUCTION}

The spread of COVID-19 has affected all citizens around the world, including the Indonesian people and the academic community at Indonesian universities. The spread of COVID-19 has stipulated as a world epidemic. Referring to the WHO's decision (Khatri, Singh, Belani, Leng, Lohan, Wei, \& Teo, 2020) that the cases spread beyond Wuhan city and on 30th Jan 2020, World Health Organization (WHO) declared the 2019 coronavirus novel (2019nCoV) outbreak as "Public Health Emergency of International Concern" (PHEIC). As per the WHO situation report of 6th February 2020, 28276 cases had been confirmed globally, 216 of which were outside China in 24 countries worldwide.

In Indonesia, it has been reported about case of COVID-19, that on Thursday (9/4/2020), there were an additional 337 new cases of COVID-19, bringing the total to 3,293 cases. Those numbers include 2761 people under treatment, 280 people died, and as many as 252 people recovered (Halim, Farisa, \& Sari, 2020). And locally, the number of patients tested positive for COVID-19 in the Malang city continues to grow. As of Tuesday, April 14, 2020, there had been 23 cases, with ten deaths. The details of the favorable COVID19 case distribution in Malang Raya are, in Malang Regency, there were 13 cases (4 recovered and one died), in Malang City, there were eight patients (7 recovered), in Batu City, there were 2 cases (1 recovered),(Arifin, 2020). From the case of COVID-19, which continues to grow, the government takes action by deciding the policy of transferring all activities carried out by physical and social distancing for infection control measures (Prem et al, 2020; Koh \& Hoenig, 2020).

Following up on the decisions of WHO and the central government, it requires massive action related to the learning model policy. As carried out at UIN Maulana Malik Ibrahim Malang, previously personal instrumental shifted to the use of online media and distance lectures. Referring to the policy regulations decided by the rector, the teaching and learning activities must be carried out online. After the significant developments of the COVID-19 pandemic, the chancellor issued a circular letter Number 1286 of 2020, regarding the Extension of the Sterilization Period of the UIN Maulana Malik Ibrahim in the Context of Anticipative Measures to Prevent the Spread of Corona Virus Disease 2019 (COVID-19) academic year 2019-2020 is fully implemented in the network system (online). The above decision is a decision that sets lectures running as online learning. Likewise, campus sterilization forces lecturers and students to conduct online lecture activities, including learning Arabic.

Arabic learning is an important concern in emergency situation of COVID-19. The learning process held in the classroom becomes online learning 
that has an impact on all activities held at home. On that basis, it needs for research that examines the process of Arabic learning and the media used in the emergency situation of COVID-19 at UIN Maulana Malik Ibrahim Malang, which is one of the universities implementing online learning during this pandemic. In practice, learning Arabic has an essential element that is emphasized, namely, the improvement of language skills that should not be stopped. Then the situation of this pandemic helped to shift the process of learning Arabic to the use of online media aimed at realizing the active involvement of students in learning. For Arabic learners, active language learning is the first approach to take. So, under any circumstances, language learning must continue to run, and the language skills must also be realized as well as possible.

Some studies (Krapchatova \& Holovko, 2018; Khalilullah, 2011) emphasized that active learning activities aim to give students many opportunities to use language. Accordingly, they are more likely to achieve fluency or communicative competence. This active collaborative interaction model indeed leads to an intensive program that is run in a commitment manner by Arabic learners; learning must also run in a structured way without being constrained by time and space even though using online networks. By being active in learning, a student will be trained continuously and repeatedly in the language training process. Suryadarma's (2016) study showed that the process of practicing is one of the most important ways to improve language skills because Arabic, as a foreign language, requires as much practice as possible. Some linguists assert that language must be practiced and used repeatedly. Linguists emphasize that linguistic competence does not come unless after continuing practice and ongoing practice. The training process also leads to a process of active collaborative interaction as an effort to realize language skills and competencies.

To face this global pandemic situation of COVID-19, with the birth of physical and social distancing policies and rules, language learning can be formulated by shifting to patterns of active collaborative interaction in online network systems. This pattern emphasizes the practice and learning activities on an ongoing basis that will produce language production and repetition of words in-depth because understanding and learning vocabulary in foreign language learning becomes an important part (Alqahtani, 2015; Daud \& Pisal, 2014; Moghadam, Zainal, \& Ghaderpour, 2012), besides also being the most critical element in improving language skills. In line with the practice and learning process, the process of collaborative active learning interactions becomes more directed, and the creation of a speaking environment can be realized even within the scope of online networks. The language environment is 
important because it will significantly help to learn Arabic for foreign speakers, both in their learning or in improving language skills (Maburoh, 2017).

The situation and conditions during the COVID-19 pandemic have brought renewable learning models to the online system. Online learning becomes an alternative learning model in the current situation, as it is based on the development of technology and communication that is overgrowing now (Sari, 2015). The development of technology and communication makes students increasingly demanding online access, and universities and colleges work to meet these demands (Song, Singleton, Hill, \& Koh, 2004). In line with that, the study (Putranti, 2013) stated that online learning enables the realization of more satisfying services to students. Likewise, students in general and Arabic language students, in particular, began to learn a lot through online networks. Various applications are used, such as YouTube, WhatsApp, Facebook, Instagram, and more. They are getting used to, and in practice, they get ease, especially in accessing learning material that is developed through ematerial (Ibrahim \& Febriani, 2018), through Blogs, Wiki, and social networking sites (Saekhow, 2015) and e-Learning (Wahono, 2018).

Online learning provides a new approach to increasing student independence. With this approach, students can process language information using peer interaction, responses, and responses provided by the teacher online. (Reinhardt, 2019) said that social media had influenced language learning massively in recent decades. It will bring a formal foreign language learning in informal learning designs without limited space and time. Besides, online learning media can facilitate students to communicate and share language information among social media users. Li (2017) revealed that online learning would provide encouragement and new experiences for students so that foreign language learning is meaningful for students.

Online-based language learning will shape transformative learning and form a constructivist approach to the discovery of the meaning of learning found independently by students. (Smith, 2017) said that the online learning process formed a constructive mindset among students. Through online media, the intensity of each student's response increases, and is even able to encourage students to ask more questions and clarifications provided by the teacher (Peeters, 2018).

So far, studies on Arabic learning tend to discuss language learning models based on three perspectives. First, the studies focus on the issue of learning the Arabic grammatical aspects as a religious language (Jauhar, 2007) with the perspective of Classical Arabic (Nikmah, 2020). Second, issues that talk about learning Arabic in the difficulty of realizing the language environment caused by the lack of native speakers (native speakers of Arabic) (Efendi, 
2018), third, studies that discuss the difficulty of determining a suitable language curriculum and have been well tested. The study (Sahkholid Nasution, 2016) shows that learning Arabic for non-Arabs - like in Indonesia - experiences a lack of clarity of learning objectives. Many curriculum developers, including Arabic language teachers and lecturers, have not formulated the objectives of learning Arabic as a foreign language for students, this has resulted in the selection of content and materials, the process and evaluation of Arabic learning that is carried out as learning Arabic in the first language context. It often makes students' motivation in learning Arabic low (Murdiono, 2018), because currently, learning Arabic is not a necessity but only fulfilling a momentary obligation (passing the test) among non-Arabic learners. It has become a significant factor for (Roziqi, 2020) to contribute to his research on the development of Arabic language material at the university level.

From this trend, it appears that learning Arabic has been built into a learning model that seeks to run the Arabic learning process with goals that are less comprehensive and only meet the needs and demands of the moment. Meanwhile, the main goal of learning Arabic is to make language the language of science, the language of international communication (Fatoni, 2019) that can meet all the needs of human life. Therefore, in an urgent situation, when the COVID-19 pandemic becomes an important symbol that Arabic covers all aspects of life that can be reached by all Arabic learners. Therefore, the efforts to learn Arabic need to be prepared as well as possible by accessing all the information and actual news online by utilizing technology and communication through the internet network.

This paper is based on the argument that increased language skills through an online network system can not only take place in situations that are very forced as the spread of the COVID-19 virus, which later became a pandemic but also can take place in a stable condition. Through online media and applications, language learning skills that have been prepared by the system, technical, and material will be able to show significant learning outcomes and be able to improve language ability. Besides, a learning system that will promote self-regulated learning (self-efficacy learning) will be built for students, because the availability of everything that is needed by students in undergoing the process of improving language skills and does not impede learning efforts and active interaction collaborative. In other words, selfregulated learning can be realized effectively in response to the difficulties of conventional learning (face-to-face), which tend to be demanding the availability of particular space and time while online learning does not require the availability of space and time, because wherever and whenever someone will be able to access knowledge and share knowledge easily. 
Based on previous research that examines learning through online platform media, such as the use of Edmodo in learning can improve students 'language experience (Taylor, 2014), the use of Skype and Zoom can improve students' ability to interact and write about conversations in foreign languages (Dharma, Asmarani, \& Dewi, 2017), besides that Google Classroom platform is able to make the situation more friendly interaction between students. Based on that, the researcher wanted to study more deeply about the Arabic learning media and the learning process at UIN Maulana Malik Ibrahim Malang.

The purpose of this paper is to complement the shortcomings of existing studies that tend to place the development of online Arabic learning as a matter of perfection and not done by many Arabic language learners. This research is different from the existing ones, emphasizing online Arabic learning as an effort that should be prepared, especially in facing technological developments and communication and becoming the consumption of generation $\mathbf{Z}$ or digital generation natively in the current era. In line with that, two questions can be formulated as follows: (a) how was the learning process of Arabic at UIN Maulana Malik Ibrahim Malang in the COVID-19 pandemic situation?; and (b) what were media used in learning Arabic at UIN Maulana Malik Ibrahim Malang in the COVID-19 pandemic situation and how can language skills be improved?.

\section{METHOD}

This paper examined the way of learning Arabic students at UIN Maulana Malik Ibrahim Malang in the COVID-19 pandemic situation. The COVID-19 pandemic situation changed the way of learning from conventional learning (face to face) to learning using an online system.

This research was a qualitative descriptive study. The data used in this paper was obtained through observation, questionnaires distributed via Google forms, online interviews through social media, and documentation. Observations were made on learning Arabic learning during the COVID-19 pandemic, and questionnaires were distributed to find out Arabic learning styles, applications used, the most desirable content, and interviews were conducted with informants selected based on constructive responses and opinions related to online learning systems.

The data are obtained through the questionnaire and distributed through the Google form application, which contains questions related to learning Arabic in a COVID-19 pandemic situation and disseminated through social media networks. The questionnaire was distributed randomly to Arabic students both in Bahasa dan Sastra Arab and Pendidikan Bahasa Arab departments from under graduate until post graduate (from bachelor until doctor degree) in UIN Maulana Malik Ibrahim Malang. From the distribution of questionnaires that 
came in, there were 129 respondents. The interviews were conducted to find out more in-depth information related to the ongoing online learning process. Ten informants were interviewed. Questions raised include issues of the online learning model of the impact of the coronavirus disease pandemic (COVID-19).

Data were analyzed in three stages, namely (1) restatement of data collected according to their respective themes, (2) description, which was carried out to find patterns and data trends, and (3) interpretations aimed at understanding the meaning contained by a statement. Data that has been reduced thematically was displayed in the form of images and statements. In the final stage, data verification was carried out to give birth to a deep and comprehensive understanding of the data.

\section{RESULTS \& DISCUSSION}

\section{Arabic Learning Process in COVID-19 Situations}

The spread of the COVID-19 pandemic has affected all elements of Indonesian citizens, including the academic community at Indonesian tertiary institutions. The impact of COVID-19 also urges universities; one of them is UIN Maulana Malik Ibrahim Malang, to respond to physical and social distancing policies by transferring the learning process online. This urgent action is a manifestation of efforts to realize success in learning in this even semester amid the COVID-19 pandemic.

The Arabic learning process was aimed to improve language skills also shifts to online-based learning. Based on the survey results, the impact of the COVID-19 pandemic directed the learning style of Arabic students to tend to model online learning, either autonomously or in groups illustrated in Figure 1.
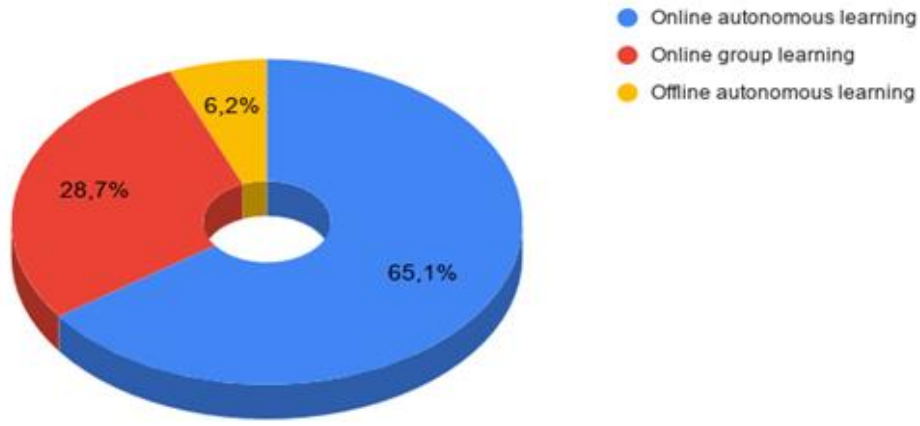

Online autonomous learning

- Online group learning

Omine autonomous learning

Figure 1. Student Learning Styles

Figure 1 illustrated that the COVID-19 pandemic situation directs student learning styles online to appear more dominant, for online learning that is run independently by $65.1 \%$ and online learning that runs with groups by $28.7 \%$, while independent learning offline or conventional learning by reading books by 
$6.2 \%$, it shows that language learning cannot be separated from the online learning process by accessing various applications and media available on the internet network. Especially in the urgent situation of the COVID-19 pandemic. Another thing that is the reason for their involvement in online networks is because of the availability of media and applications that are currently very easy to obtain, especially accompanying the study from home policy and the current physical and social distancing policy.

In practice, independent online learning is a very significant shift. The COVID-19 pandemic situation provides limited space for students to learn. By studying autonomously, students can easily apply a learning approach that aims to regulate themselves both the motivation and desires of themselves and the expectations they want to achieve. This independent online learning also provides flexibility in accessing online learning materials, broadening the horizons of knowledge, so that knowledge is used as a provision for the development and improvement of language skills they have. In line with the statement (Zimmerman, 2000; Zimmerman, 2011; Dabbagh \& Kitsantas, 2012; Azmi, 2016) that independent learning involves aspects of students' cognition, motivation, and behavior in carrying out learning activities, Such learning leads to the personal life of each individual in viewing learning for himself as having responsibility, as a control for the acquisition of their knowledge. So that time management and increased knowledge and achievement can be managed privately.

On the other hand, language learning dramatically influences one's skills and knowledge in understanding language. Language learning is a story, not just a vocabulary where the language is used as a necessary process in interpreting and regulating understanding and experience (Gooptu \& Chakravarty, 2018). Language learning is the process of understanding or abstracting meaning, interpretation, and understanding of reality in a different way (Fatimah \& Sari, 2018). Therefore, language learning can support the creation of a critical understanding and sensitivity to each individual. Language as a tool to influence, change and dominate others so that readers or audiences who will receive and justify messages, ideas, thoughts conveyed believe and even follow it. Everyone needs language when interacting, expressing ideas and opinions, and other social relationships. As language is of great significance for social relations, it is essential to pay attention to language learning (Alqahtani, 2015; Melitz, 2016; Moghadam, Zainal, \& Ghaderpour, 2012)

Success in language learning is related to age, talent, motivation, previous language learning experiences, learning styles, beliefs, culture, gender, and self-direction (Hardison, Miller, Li, Schroeder, Burkhauser, Robson, \& Lai, 2012). The case study by Wengan and Yaya (2013) conducted in China 
shows that culture influences language learning beliefs and has a significant influence on many of the failures and efficiency of language learning in language learning. Therefore, Self-Regulated Learning is very appropriate if it is run in a COVID-19 pandemic situation, and as a learning model solution that can be run without constrained by time and space. However, maximum results will also be achieved if the learning process can be carried out actively collaboratively even though it is carried out using online media. In line with the statement (Mandusic \& Blaskovic, 2015) which states that active learning has significantly changed the role of students because they have to be responsible for their learning. Students develop personal skills and positive attitudes toward learning. This can also be supported by collaborative learning that can direct learners to exchange progressive ideas that not only increase learning interest but also promote critical thinking (Gokhale, 1995), as well as providing opportunities for students to engage in discussion, take responsibility for their learning and their group (Gokhale, 2012).

\section{Arabic Learning Media in COVID-19 Situations}

Media and applications on the internet are not just social media or media that they use to establish communication, fill in free time or entertainment. In this COVID-19 pandemic situation, the presence of online media and applications provides more value and benefits to the academic world. The maximum use of online media and applications on the internet can help realize success and success in learning. As the results of the response to the current COVID-19 pandemic, UIN Maulana Malik Ibrahim Malang students are directed to further optimize online applications as a medium and source of learning Arabic. Based on the survey results, several media and applications that are quite familiar among students and currently used for the learning process are WhatsApp, YouTube, and Instagram. Student responses in the use of media and online applications can be seen in Figure 2;

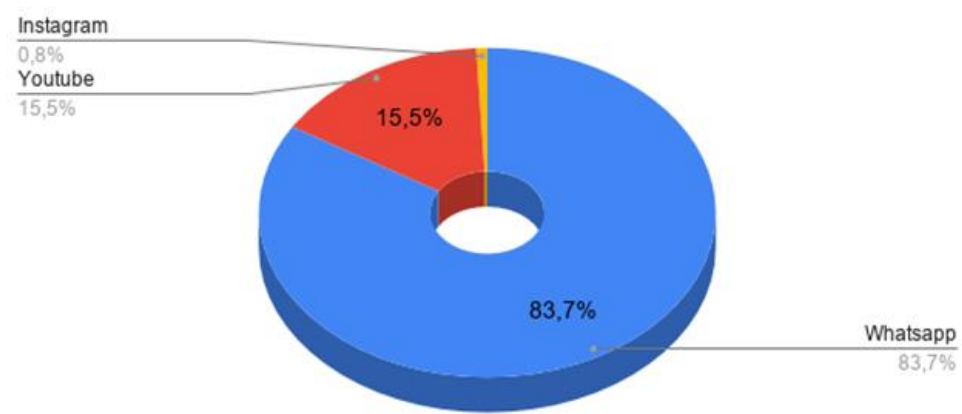

Figure 2. Media \& Applications for Learning Arabic 
From Figure 2, it appears that the majority of students use the WhatsApp application in carrying out the Arabic learning process, amounting to $83.7 \%$ and the use of the YouTube application $15.5 \%$, while Instagram $0.8 \%$.

The WhatsApp application is the most widely used media in the learning process because through the WhatsApp application, a group discussion can be formed, which contains all students who are involved in learning Arabic. Through WhatsApp, anyone can share learning materials, either in the form of Microsoft Word files, PPt files, Pdf files, videos, Voice Notes, and sharing learning network link resources, as well as being used to conduct teleconferences.

In addition to the media and applications above, some several other online media and applications are utilized in the process of learning Arabic at UIN Maulana Malik Ibrahim Malang. The COVID-19 pandemic situation provides a breakthrough in the introduction of online media that can be utilized for the Arabic learning process, including the Vmeet and e-Learning application created by the IT team of UIN Maulana Malik Ibrahim Malang. Besides, there is the Zoom Cloud application and Google Classroom, while other applications used as learning resources are Academic Skills and Al-Jazeerah.com. From the use of online media and applications, there is compelling content that is accessed by students. The survey results of some media content and online applications accessed by students can be seen in the following Figure 3;

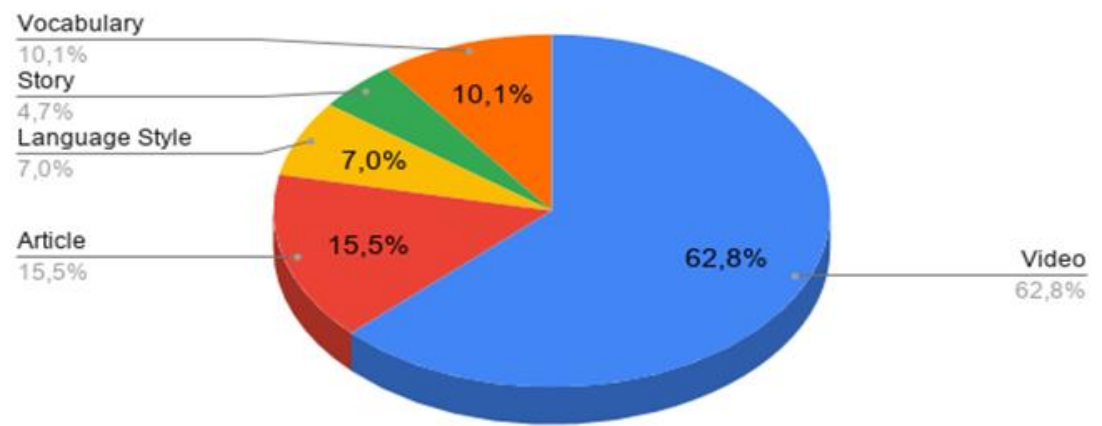

Figure 3. The Content that is Accessed by Students

As illustrated in Figure 3 it appears that students prefer to choose learning material through video media, from the survey results it can be seen that the total number of processes that access video content is $62.8 \%$, articles are $15.5 \%$, vocabulary is $10.1 \%$, language style content is $7.0 \%$ and story content $4.7 \%$.

The utilization of technology through the internet that can be accessed through films (Adnan, 2014), YouTube (Combe \& Codreanu, 2016), written blog posts and video blogs (Arndt \& Woore, 2018; Watkins, 2012) and social media (Li, 2017), provide a meeting point for each of the existing technological 
developments. Indeed, the use of these technologies aims to introduce students to the context of the language and various vocabularies learned in the second language. As the study (Jalaluddin, 2016) confirms that technology has a vital role in language learning and teaching, technological advances have opened many ways for teachers and students to apply online resources in their learning and teaching.

The use of online media and applications in the COVID-19 pandemic situation also shows students' positive efforts in language practice as an effort to improve language skills. As illustrated in Figure 4;

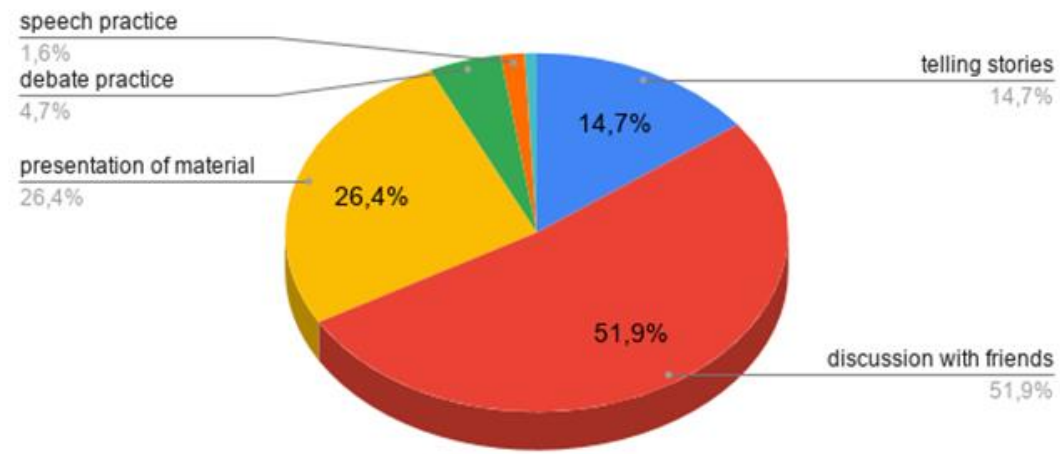

Figure 4. The Practices for Improving Language Skills

Source: Research Results, 2020

In Figure 4 it appears that Arabic learning that is carried out with online language practice tends to practice speaking, as the survey results show that in discussions with friends by $51.9 \%$, presentation of material and giving feedback to each other by $26.4 \%$, telling stories by $14.7 \%$, debate practice by $4.7 \%$ and speech practice by $1.6 \%$.

Various ways in language learning for language learners 2 (L2) to this day continue to be explored by experts. There are many innovative learning methods developed to realize quality improvement in language skills. The study (Dajani, 2015) showed that Arabic requires changes in teaching methods for native speakers, as well as for speakers of other languages. From the process of learning the language being carried out, the emphasis is on improving language skills. Quoting from (Dockrell \& Marshall, 2015), the development and honing of language skills is a central ability for every individual to engage in social relations and access compelling learning experiences. The Dickinson \& Porche (2011) study emphasizes that language skills are fundamental in influencing the abilities and knowledge of every child from reading, writing, speaking, and listening. Therefore, language skills influence students to have high intellectual and thought patterns in components such as critical thinking, evaluation, and research (Gil-Glazer, Walter, Eilam, 2019).

There are some skills that can be improved through online language learning, namely: a) learners still get guidance and supervision from the 
teacher, b) knowledge of language skills that are formed through the construction of language meaning, c) communication and integration of each language skill including listening, speaking, reading and writing so that there is integrated and holistic learning, d) some language games can also improve students' critical thinking processes by solving problems, e) learning can be designed contextually ( $\mathrm{Li}, 2017)$.

In fact, language skills can be maximized and integrated through technology (Picciano, 2017). The language learning process should not involve conscious effort so that language skills will become a habit. For example, children have the opportunity to speak a foreign language faster because they learn a foreign language through habits, and hence, may adopt online language learning. He revealed that spontaneous reactions are highly expected in language learning (Ismail, Zailani, Awad, Hussin, Faisal, \& Saad, 2017).

This COVID-19 pandemic situation demands an online learning style by optimizing the use of advanced technology. From the study (Oddone, 2011), it is shown that the use of the internet makes it easy for students to access various available websites. Web sites on the internet have provided video lessons, documentaries, entertainment, and educational material related to learning Arabic. Thus, Arabic students can access the site and will provide benefits in learning, in line with the statement (Ms, Dellit, \& Secretariat, 2001) that the existence of ICT (Information Communication Technology) in learning provides benefits if used and utilized as well as possible, and can make a very significant difference if used correctly by teachers and learners (Higgins, 2003).

Through the description of the data above, it is known that the researchers found that students were actively involved in the use of technology to regulate various aspects of their language learning experiences actively, such as how to improve speaking skills. Students can access knowledge and language skills more broadly and not limited to place and time through a variety of features available in online media. It is in line with Suherdi's (2013) statement that technology can help students in active and independent learning. Besides, Lamb revealed that technology could be a real opportunity to facilitate teachers and lecturers in delivering teaching material (Lamb \& Arisandy, 2020).

Other opportunities are also offered through social media for the use of language for its users, and this is an embodiment of language acquisition interactions (Slim \& Hafedh, 2019). It can be facilitated through various existing applications to increase four language skills equally, and students have experience by writing various contexts, listening to various conversations, and reading a variety of literature that can achieve the desired foreign language learning goals. 
However, there are real and fundamental differences when social media is used as a medium for learning by using technology for social communication purposes. There are some reasons behind the marked difference in using technology to regulate student language learning. It can be shown when there are differences in the language skills of each individual in processing information through technology, especially information about learning Arabic. Some of these facts can map students' metacognitive knowledge about how to use technology effectively, prepare for effective communication interactions, and encourage student confidence in learning foreign languages specifically (Kılıçkaya, 2020). On that basis, an educator must be more extra to provide learning instructions that are easier for students to apply in learning Arabic online.

The most important thing is the power of technology for language learners can be realized and maximized outside the language classroom because, after all, student acceptance of the value of technology, and its use is very affirmative (Lai \& Gu, 2011). Kern (2014) argued that globalization has changed the context, means, and use of foreign language learning.

According to the data, YouTube is also used as a medium of learning by students. Through the YouTube media, students can gain some integrated language skills, such as when a learner watches a video, he will gain collaborative skills improvement, such as absorption of new vocabulary, proper pronunciation, and sound intonation of sound in reciting words that have been listened carefully. Through video watching activities, students can maximize listening skills and encourage increased productive skills (speaking and writing). Along with Hung's research that YouTube has a vital role in providing favorable access to the encouragement of learner language skills (Hung, Lu, \& Yeh, 2017).

Learning activities through debate and discussion provide the potential for increased language skills in students because learners provide and respond to Arabic information conveyed from friends or lecturer supervisors. However, some concrete steps that need to be done by the teacher are guidelines on how to use specific technological resources in unlimited time. The ignorance of the teacher or lecturer in guiding and adopting practical instructions will affect students' interest in learning Arabic. The more creative a teacher is, the better the students' response to language learning (Rusdin, 2018) so that students will have more motivation to learn Arabic, the most important is the teacher's efforts to help students reap the benefits of technology to support their learning of Arabic.

Some tutorials and instructional instructions must be given to students because technology provides options to enhance the interaction of positive 
speaking skills in using Arabic. When learning speaking skills in class, it is not uncommon for students to have anxiety and worries in speaking Arabic. However, when lecturers and students interact through technology, students compete in uploading their learning outcomes on social media. Based on facts like that, technology can help students' creative thinking processes.

Today's language learners also enjoy new projects as video producers because, at their fingertips, there are various digital video tools, which they routinely use to upload recordings to YouTube and other media. Through technology intermediaries, students get positive responses from several people who help justify their mistakes in speaking. For example, when students upload their conversion process to the YouTube application, some people comment on their mistakes, starting with pronunciation or vocabulary. This activity also helps the teacher in correcting each student in learning speaking skills.

\section{CONCLUSIONS}

The growing research literature is now proving the power of various forms of media to motivate Arabic learners from elementary to university levels during the COVID-19 emergency. The process of learning Arabic in the COVID19 pandemic situation by UIN students Maulana Malik Ibrahim Malang through various types of online media. Some of the media used are WhatsApp, YouTube, and Instagram. Students' Arabic language skills can be improved through videos, material presentations, debates, and online discussions. This study found a shift in Arabic learning at UIN Maulana Malik Ibrahim Malang students from personal to instrumental as a result of the COVID-19 pandemic situation. A transformation occurred in Arabic learning from a personal-cultural approach to an instrumental-functional approach. This shift in the pattern also changed the dependency from dependence on teachers to dependency on technology in the COVID-19 pandemic situation. This research also found that Arabic learning in an integral and holistic system is able to provide language skills output well for students. This study recommends other researchers to uncover the resolution of obstacles experienced by students when learning online during the COVID 19 emergency response period.

\section{ACKNOWLEDGMENT}

We present this article to Arabic language lovers, Arabic Language Education Students, Arabic Language, and Literature Students at UIN Maulana Malik Ibrahim Malang; for the bachelor, master, and doctoral level. 


\section{BIBLIOGRAPHY}

Adnan, A. (2014). Improving Students ' Listening Ability through Movie Report. Proceedings of ISelt FBS Universitas Negeri Padang., 69-75.

Al-Shbail, A. O., \& Diab, M. A. B. (2018). Arabic Writing, Spelling Errors and Methods of Treatment. Journal of Language Teaching and Research, 9(5), 1026-1035. DOI: https://doi.org/10.17507/j|tr.0905.17

Alqahtani, M. (2015). The Importance Of Vocabulary In Language Learning And How To Be Taught. International Journal of Teaching and Education. International Institute of Social and Economic Sciences, 3(3), 21-34. DOI: https://doi.org/10.20472/te.2015.3.3.002

Arifin, Z. (2020). Update Corona Covid-19 di Malang Raya, 23 Kasus Positif dan 10 Meninggal Dunia. Liputan6.Com. Retrieved from https://www.liputan6.com/regional/read/4227708/update-corona-covid-19di-malang-raya-23-kasus-positif-dan-10-meninggal-dunia

Arndt, H. L., \& Woore, R. (2018). Vocabulary learning from watching YouTube videos and reading blog posts. Language Learning \& Technology, 22(3), 124-142. https://scholarspace.manoa.hawaii.edu/handle/10125/44660

Azmi, S. (2016). Self Regulated Learning Salah Satu Modal Kesuksesan Belajar dan Mengajar. Seminar Asean. 2nd Psychology \& Humanity (C) Psychology Forum UMM, 19 - 20 Februari 2016, 401-406. http://mpsi.umm.ac.id/files/file/400-406\%20Shofiyatul\%20Azmi.pdf

Combe, C., \& Codreanu, T. (2016). Vlogging: a New Channel For Language Learning And Intercultural Exchanges. In CALL communities and culture short papers from EUROCALL 2016. 119-124. DOI: https://doi.org/10.14705/rpnet.2016.eurocall2016.548

Dabbagh, N., \& Kitsantas, A. (2012). Personal Learning Environments, Social Media, And Self-Regulated Learning: A Natural Formula For Connecting Formal And Informal Learning. Internet and Higher Education, 15(1), 3-8. DOI: https://doi.org/10.1016/j.iheduc.2011.06.002

Dajani, B. A. S. (2015). Teaching Arabic Language: Towards a New Beginning that Stimulates Creativity. Procedia - Social and Behavioral Sciences, 192, 754-763. DOI: https://doi.org/10.1016/j.sbspro.2015.06.086

Daud, N., \& Pisal, N. A. (2014). Speaking problems in Arabic as a second language. GEMA Online Journal of Language Studies, 14(1)117-133. DOI: https://doi.org/10.17576/GEMA-2014-1401-08

Dharma, H. R. C., Asmarani, D., \& Dewi, U. P. (2017). Basic Japanese Grammar and Conversation e-learning Through Skype and Zoom Online Application. Procedia Computer Science, 116, 267-273. DOI: https://doi.org/10.1016/j.procs.2017.10.055 
Dickinson, D. K., \& Porche, M. V. (2011). Relation Between Language Experiences in Preschool Classrooms and Children's Kindergarten and Fourth-Grade Language and Reading Abilities. Child Development, 82(3), 870-886. DOI: https://doi.org/10.1111/j.1467-8624.2011.01576.x

Dockrell, J., \& Marshall, C. (2015). Measurment Issues: Assessing Language Skills In Young Children. Child and Adolescent Mental Health, 20(2), 116125,DOI: https://doi.org/10.1111/camh.12072,

Efendi, A. (2018). Dhawahir al-Lughah al-Arabiyah wa ash-Shu'uubaat allatiy Yuwaajihuhaa an-Naatiquuna bi Ghayrihaa. Al-Manar, 2(8), 117-133. DOI: https://doi.org/10.24014/al-manar.v2i8.4731

Fatimah, \& Sari, R. D. K. (2018). Strategi Belajar \& Pembelajaran dalam Meningkatkan Keterampilan Bahasa. Pena Literasi, 1(2), 108-113, DOI: https://doi.org/10.24853/pl.1.2.108-113

Fatoni, A. (2019). Arabic Learning for Academic Purposes. Izdihar: Journal of Arabic Language Teaching, Linguistics, and Literature, 2(2), 149-164. DOI: https://doi.org/10.22219/jiz.v2i2.10096

Gil-Glazer, Y., Walter, O., \& Eilam, B. (2019). PhotoLingo-Development and Improvement of Higher-Order Thinking and Language Skills Through Photographs. Journal of Education, 199(1), 45-56. DOI: https://doi.org/10.1177/0022057419843523

Gokhale, Anu A. (2012). Collaborative Learning and Critical Thinking. In Encyclopedia of the Sciences of Learning. DOI: https://doi.org/10.1007/978-1-4419-1428-6 910

Gokhale, Anuradha A. (1995). Collaborative Learning Enhances Critical Thinking. Journal of Technology Education, 71$)$. DOI: https://doi.org/10.21061/jte.v7i1.a.2

Gooptu, N., \& Chakravarty, R. (2018). Skill, Work and Gendered Identity in Contemporary India: The Business of Delivering Home-Cooked Food for Domestic Consumption. Journal of South Asian Development, 13(3), 293314. DOI: https://doi.org/10.1177/0973174118804448

Graves, M. F., August, D., \& Mancilla-Martinez, J. (2012). Teaching vocabulary to English language learners. New York: Teachers College Press

Halim, D., Farisa, F. C., \& Sari, H. P. (2020). UPDATE: Kasus Covid-19 di Indonesia Total 3.293, Bertambah 337. Kompas. Retrieved from https://nasional.kompas.com/read/2020/04/09/15434301/update-kasuscovid-19-di-indonesia-total-3293-bertambah-337?page=all

Hardison, C. M., Miller, L. W., Li, J. J., Schroeder, A. N., Burkhauser, S., Robson, S., \& Lai, D. (2012). Background on Adult Language Learning. In Second-Language Skills for All?, Santa Monica:Rand Corporation 
Higgins, S. J. (2003). Does ICT improve learning and teaching in schools?. BERA, British Educational Research Association

Hung, H., Lu, Y., \& Yeh, H. (2017). Emerging Technologies for Education - First International Symposium, \{SETE\} 2016, Held in Conjunction with \{ICWL\} 2016, Rome, Italy, October 26-29, 2016, Revised Selected Papers. Springer International Publishing AG 2017, 10108, 225-239. DOI: https://doi.org/10.1007/978-3-319-52836-6

Ibrahim, D. S. M., \& Febriani, Y. (2018). Pengembangan E-Materi Berbasis Mata Kuliah Pada Pembelajaran Jarak Jauh (E-Learning). Jurnal DIDIKA: Wahana IImiah Pendidikan Dasar. 4(12.)1-16. DOI: https://doi.org/10.29408/didika.v4i2.1170

Islam, M. S. (2019). Bangladeshi University Students' Perception about Using Google Classroom for Teaching English. International Journal of PsychoEducational Sciences, 57-65. https://www.journals.lapub.co.uk/index.php/IJPES/article/view/1165.

Ismail, W., Zailani, M. A., Awad, Z. A. M., Hussin, Z., Faisal, M., \& Saad, R. (2017). Academic and social media practices of arabic language among malaysian students. Turkish Online Journal of Educational Technology TOJET, 16(3), 1-10._Call Number: https://eric.ed.gov/?id=EJ1152657

Jalaluddin, M. (2016). Using YouTube to Enhance Speaking Skills in ESL Classroom. English for Specific Purposes World. 750) http://espworld.info/

Jauhar, N. I. (2007). Ittijaahaat Jadiidah Fi Majaali Taklim al-Lughah alArabiyah fi Induniisiya. Journal Of Indonesian Islam, 1(2), 420-428. DOI: https://doi.org/10.15642/JIIS.2007.1.2.420-441

Kern, R. (2014). Technology as Pharmakon: The promise and perils of the Internet for foreign language education. Modern Language Journal, 98(1), 340-357. DOI: https://doi.org/10.1111/j.1540-4781.2014.12065.X

Khalilullah, M. (2011). Strategi Pembelajaran Bahasa Arab Aktif (Kemahiran Istima' dan Takallum). Sosial Budaya, 8(2), 152-167. DOI: http://dx.doi.org/10.24014/sb.v8i2.360

Khatri, P., Singh, S. R., Belani, N. K., Yeong, Y. L., Lohan, R., Lim, Y. W., \& Teo, W. Z. (2020). YouTube as Source of Information on 2019 Novel Coronavirus Outbreak: A Cross Sectional Study of English and Mandarin Content. Travel Medicine and Infectious Disease, 35(3). 1-31. DOI: https://doi.org/10.1016/j.tmaid.2020.101636

Kılıçkaya, F. (2020). Learners' Perceptions Of Collaborative Digital Graphic Writing Based On Semantic Mapping. Computer Assisted Language Learning, $33(1-2), 58-84$. DOI: https://doi.org/10.1080/09588221.2018.1544912 
Koh, G. C.-H., \& Hoenig, H. (2020). How Should the Rehabilitation Community Prepare for 2019-nCoV? Archives of Physical Medicine and Rehabilitation, 101(6), 1-10. DOI: https://doi.org/10.1016/j.apmr.2020.03.003

Krapchatova, Y., \& Holovko, O. (2018). The Use Of Interactive Technologies For Improving Communicative Competence In Listening And Speaking Of Students Of Higher Educational Institutions. Visnyk Taras Shevchenko National University of Kyiv. Pedagogy, 71$)$, 36-39. DOI: https://doi.org/10.17721/2415-3699.2018.7.09

Lai, C., \& Gu, M. (2011). Self-regulated out-of-class language learning with technology. Computer Assisted Language Learning, 24 (4), 317-335. DOI: https://doi.org/10.1080/09588221.2011.568417

Lamb, M., \& Arisandy, F. E. (2020). The impact of online use of English on motivation to learn. Computer Assisted Language Learning, 33 (1-2), 85108. DOI: https://doi.org/10.1080/09588221.2018.1545670

Li, V. (2017). Social Media in English Language Teaching and Learning. International Journal of Learning and Teaching, 3(2). 148-153. DOI: https://doi.org/10.18178/ijlt.3.2.148-153

Maburoh, M. (2017). Al-Bii'ah al-Lughawiyyah al-Arabiyyah fi Taklim al-Lughah al-Arabiyyah Li Ghayr an-Naatiqiina Biha. Alfazuna: Jurnal Pembelajaran Bahasa Arab Dan Kebahasaaraban, 2(1), 28-41. DOI: https://doi.org/10.15642/alfazuna.v2i1.245

Mandusic, D., \& Blaskovic, L. (2015). The Impact Of Collaborative Learning To Critically Thinking. Trakia Journal of Science, 13 (1), 426-428. DOI: https://doi.org/10.15547/tjs.2015.s.01.073

Melitz, J. (2016). English As A Global Language. In The Palgrave Handbook of Economics and Language. 263-264. DOI: https://doi.org/10.1007/978-1137-32505-1

Moghadam, S. H., Zainal, Z., \& Ghaderpour, M. (2012). A Review on the Important Role of Vocabulary Knowledge in Reading Comprehension Performance. Procedia - Social and Behavioral Sciences, 66, 555-563. DOI: https://doi.org/10.1016/j.sbspro.2012.11.300

Ms, B., Dellit, J., \& Secretariat, L. F. (2001). Using ICT for Quality in TeachingLearning Evaluation Processes. Management. 56-66.

http://ictliteracy.info/rf.pdf/UsingICTQuality.pdf.

Murdiono. (2018). Dirasah Halah an Muyuli Thalabah fi Ta'lumi Al-Lughah AlArabiyah bil Madarisi Al-mutawashitah Al-Isamiyah bi Malang wa Batu. Izdihar: Journal of Arabic Language Teaching, Linguistics, and Literature, 1(2), 153-166. DOI:

https://doi.org/https://doi.org/10.22219/izdihar.v1i2.7297

Nikmah, K. (2020). Interrogative Sentence: A Contrastive Study of Arabic and 
Indonesian. Izdihar: Journal of Arabic Language Teaching, Linguistics, and Literature, 2 (3), 183-200. DOI: https://doi.org/10.22219/jiz.v2i3.10148

Oddone, C. (2011). Using Videos from YouTube and Websites in the CLIL Classroom. Studies About Languages, (18), 105-110. DOI:

https://doi.org/10.5755/j01.sal.0.18.417

Peeters, W. (2018). Applying the networking power of Web 2.0 to the foreign language classroom: a taxonomy of the online peer interaction process. Computer Assisted Language Learning, 31(8), 905-931. DOI: https://doi.org/10.1080/09588221.2018.1465982

Picciano, A. G. (2017). Theories and frameworks for online education: Seeking an integrated model. Online Learning Journal, 21(3), 166-190. DOI: https://doi.org/10.24059/olj.v21i3.1225

Prem, K., Liu, Y., Russell, T. W., Kucharski, A. J., Eggo, R. M., Davies, N., ... \& Abbott, S. (2020). The effect of control strategies to reduce social mixing on outcomes of the COVID-19 epidemic in Wuhan, China: a modelling study. The Lancet Public Health, 5(5), e261-e270. DOI: https://doi.org/10.1016/s2468-2667(20)30073-6

Putranti, N. (2013). Cara Membuat Media Pembelajaran Online Menggunakan Edmodo. Jurnal Pendidikan Informatika Dan Sains, 2(2), 139-147. DOI: http://dx.doi.org/10.31571/saintek.v2i2.224

Reinhardt, J. (2019). Social media in second and foreign language teaching and learning: Blogs, wikis, and social networking. Language Teaching, 52 (1), 1-39.DOI: https://doi.org/10.1017/S0261444818000356

Roziqi, M. A. (2020). Development of Pictorial Textbook for Arabic Speaking Skill in Islamic Studies Program. Izdihar: Journal of Arabic Language Teaching, Linguistics, and Literature, 2(3), 217-230. DOI: https://doi.org/10.22219/jiz.v2i3.10161

Rusdin, N. M. (2018). Teachers' Readiness in Implementing 21st Century Learning. International Journal of Academic Research in Business and Social Sciences, 8(4), 1293-1306. DOI: https://doi.org/10.6007/ijarbss/v8i4/4270

Saekhow, J. (2015). Steps of Cooperative Learning on Social Networking by Integrating Instructional Design based on Constructivist Approach. Procedia - Social and Behavioral Sciences, 195, 1740-1744. DOI: https://doi.org/10.1016/j.sbspro.2015.07.230

Sahkholid Nasution. (2016). Ahdaaf Taklim al-Lughah al-Arabiyyah Li Ghayr anNaatiqiina Biha. Jurnal Tarbiyah, 23(2). 380-401. DOI: http://dx.doi.org/10.30829/tar.v23i2.230

Sari, P. (2015). Memotivasi Belajar Dengan Menggunakan E-Learning. Ummul Quro. 6(2) 20-35. 
http://ejournal.kopertais4.or.id/pantura/index.php/qura/article/view/2048

Slim, H., \& Hafedh, M. (2019). Social media impact on language learning for specific purposes: A Study In English For Business Administration. Teaching English With Technology, 19 (1), 56-71.

https://www.ceeol.com/search/article-detail?id $=737372$

Smith, E. E. (2017). Social media in undergraduate learning: categories and characteristics. International Journal of Educational Technology in Higher Education, 14 (1),1-24. DOI: https://doi.org/10.1186/s41239-017-0049-y

Song, L., Singleton, E. S., Hill, J. R., \& Koh, M. H. (2004). Improving Online Learning: Student Perceptions Of Useful And Challenging Characteristics. Internet and Higher Education. 7(1).59-70. DOI:

https://doi.org/10.1016/j.iheduc.2003.11.003

Suherdi, D. (2013). Buku Pedoman Penyelenggaraan Pendidikan Profesi Guru Bahasa Inggris. Bandung: CELTICS Press

Suryadarma, Y. (2016). Attadriibaat al-Lughawiyyah al-Musyawwiqaat fi Taklim al-Lughah al-Arabiyyah 'Ala Dhau al-Maharat al-Kitabah. LISANUDHAD, 3(2). 53-68. DOI: https://doi.org/10.21111/LISANUDHAD.V3I2.1107

Taylor, M. C. (2014). Using a Social Learning Network As A Second Language Acquisition Tool For Adult English Language, 2(1), 46-62. https://eric.ed.gov/?id=EJ1227527

Wahono, R. S. (2018). Sistem E-Learning Berbasis Model Motivasi Komunitas. Jurnal Teknodik, 21(3), 228-248. DOI:

https://doi.org/10.32550/teknodik.v21i3.469

Watkins, J. (2012). Increasing Student Talk Time Through Vlogging. Language Education in Asia. 3(2), 196-203, DOI:

https://doi.org/10.5746/leia/12/v3/i2/a08/watkins

Wengan, J., \& Yaya, Z. (2013). The Effects Of Culture On Foreign Language Learning Beliefs. Proceedings of the 2013 IEEE International Conference in MOOC, Innovation and Technology in Education, MITE 2013. 380-385. DOI: https://doi.org/10.1109/MITE.2013.6756372

Zimmerman, B. J. (2000). Self-Efficacy: An Essential Motive to Learn. Contemporary Educational Psychology, 25(1), 82-91. DOI: https://doi.org/10.1006/ceps.1999.1016

Zimmerman, B. J. (2011). Motivational Sources And Outcomes Of SelfRegulated Learning And Performance. In B. J. Zimmerman \& D. H. Schunk (Eds.), Educational Psychology Handbook Series. Handbook Of Self-regulation of learning and performance (49-64). Routledge/Taylor \& Francis Group. 